\title{
Mycotic pseudoaneurysm of the common carotid artery: an unusual neck lump
}

\author{
Olivia Kenyon (1) , ${ }^{1}$ Ravina Tanna, ${ }^{1}$ Vishali Sharma, ${ }^{2}$ Peter Kullar ${ }^{1}$
}

${ }^{1}$ Department of ENT, Lister Hospital, Stevenage, UK ${ }^{2}$ Department of General Surgery, Lister Hospital, Stevenage, UK

\section{Correspondence to} Ms Olivia Kenyon; livykenyon@doctors.org.uk

Accepted 3 November 2020

\section{DESCRIPTION}

A 62-year-old man with hypertension and gout presented to the emergency department with an increasing left-sided neck lump. The lump had been present for 3 weeks but had significantly increased in size that day. There was no history of neck trauma or infection. The patient was haemodynamically stable with a New Early Warning Score of 0 . He had no shortness of breath, no stridor and a normal swallow. On examination he had a $10 \times 10 \mathrm{~cm}$ neck lump at levels II-III with no overlying erythema or tenderness. Oropharyngeal examination was normal. Flexible nasendoscopy revealed a normal epiglottis and smooth, mobile vocal cords with a left-sided pharyngeal swelling occluding 25\% of the airway. His inflammatory markers were raised (white cell count $18.9 \times 10^{9} / \mathrm{L}$, C-reactive protein $86 \mathrm{mg} / \mathrm{L})$. He was commenced on intravenous metronidazole and teicoplanin, and dexamethasone to reduce airway oedema.

A CT neck demonstrated a large $(31 \times 29 \times 25 \mathrm{~mm})$ mycotic pseudoaneurysm of the left common carotid artery (CCA) arising $36 \mathrm{~mm}$ from the carotid bifurcation with a linear foreign body, suspected to be a fish bone, exiting the oesophagus (figures 1 and 2). On further discussion the patient did not recall any history of fish bone ingestion.

The patient underwent emergency surgery as a joint otolaryngology and vascular surgery case. The aneurysm arose from a defect of $15 \times 10 \mathrm{~mm}$ with surrounding pus. A $30 \mathrm{~mm}$ section of CCA was excised as primary aneurysmorrhaphy and repaired

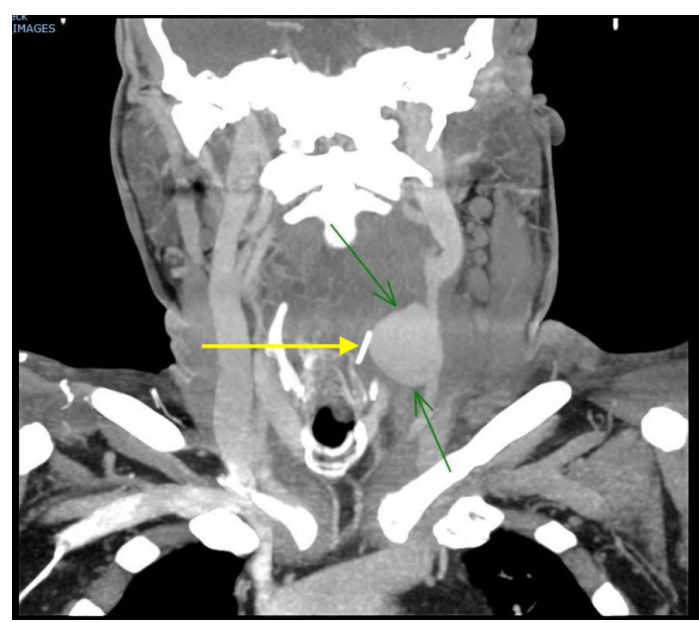

Figure 1 Coronal view of left common carotid artery pseudoaneurysm (green arrows indicating pseudoaneurysm; yellow arrow indicating linear foreign body exiting the oesophagus).

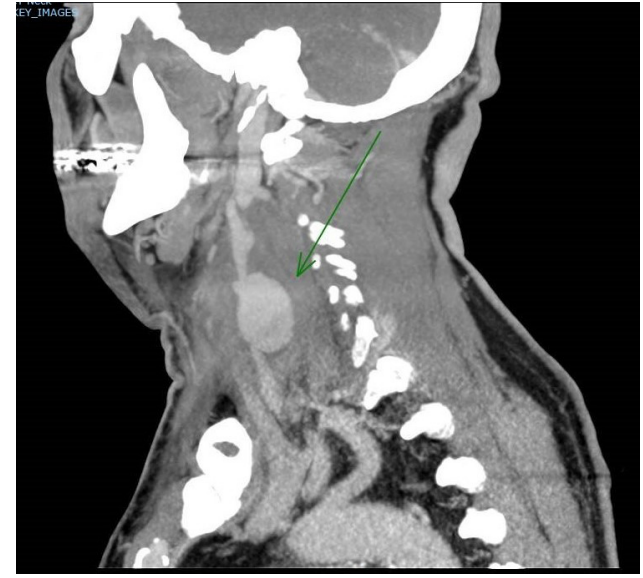

Figure 2 Sagittal view of left common carotid artery pseudoaneurysm (green arrow indicating pseudoaneurysm).

\section{Learning points}

- Although rare, vascular injury and subsequent pseudoaneurysm is an important differential and should always be considered in those presenting with neck swelling.

- Foreign bodies in the upper aerodigestive tract are a common otolaryngology emergency and usually easily dealt with however they may result in significant complications so care should be taken-particularly batteries and bones.

with a reversed long saphenous vein graft. Subsequently his neck was explored but the foreign body was not visualised despite using an image intensifier. A rigid pharyngo-oesophagoscopy was performed with no defect identified. The neck was closed in layers with vicryl and interrupted skin sutures and a vacuum drain.

$\mathrm{He}$ was anticoagulated with aspirin and was extubated after 2 days on the Intensive Care Unit. A nasogastric tube provided enteral nutrition until a barium swallow confirmed no pharyngeal leak. A CT scan was performed after 12 days for rising inflammatory markers showing a collection of fluid and gas. This was managed conservatively with 6 weeks of empirical antibiotics as microscopy and cultures from the intraoperative swab found no organisms. Successful resolution was observed by serial CT scanning. At follow-up he was diagnosed with a complete left vocal cord palsy with phonatory gap and is awaiting an injection thyroplasty. 
Mycotic aneurysms are irreversible vascular dilatations from an infective arteritis that damages the vessel wall. The name refers to the fungal-like appearance when originally described by Osler in 1885 rather than microbiological aetiology. ${ }^{1}$ Almost all untreated infected aneurysms eventually lead to rupture and haemorrhage. ${ }^{2}$ Carotid mycotic aneurysms are extremely rare with a reported incidence of 2-20 cases per year; comprising 5\% of all mycotic aneurysms. ${ }^{3-5}$ They usually occur between sixth and seventh decades of life, in immunocompromised patients, and often as a complication of iatrogenic vascular trauma or systemic sepsis from a distant infectious source e.g. endocarditis. ${ }^{6}$

This case is unique as we propose that an asymptomatic ingested fishbone perforated the oesophagus and CCA causing vascular trauma. This acted as a nidus for infection resulting in the mycotic aneurysm.

Contributors OK was involved in the patient's admission and care on the ward and decided it would be an interesting case to write up with the team. She planned the case report, was involved in the writing and background information and completed the manuscript. RT and VS were involved in writing the case report. PK was one of the operating surgeons, and supervised and edited the manuscript.
Funding The authors have not declared a specific grant for this research from any funding agency in the public, commercial or not-for-profit sectors.

Competing interests None declared.

Patient consent for publication Obtained.

Provenance and peer review Not commissioned; externally peer reviewed.

\section{ORCID iD}

Olivia Kenyon http://orcid.org/0000-0003-3633-7206

\section{REFERENCES}

1 Osler W. The Gulstonian lectures, on malignant endocarditis. Br Med J 1885;1:467-70.

2 Kim Y-wook, Kim Y-W. Infected aneurysm: current management. Ann Vasc Dis 2010;3:7-15.

3 Pirvu A, Bouchet C, Garibotti FM, et al. Mycotic aneurysm of the internal carotid artery. Ann Vasc Surg 2013;27:826-30.

4 Grau C, Johansen LV, Jakobsen J, et al. Cervical lymph node metastases from unknown primary tumours. results from a national survey by the Danish Society for head and neck oncology. Radiother Oncol 2000;55:121-9.

5 Rice HE, Arbabi S, Kremer R, et al. Ruptured Salmonella mycotic aneurysm of the extracranial carotid artery. Ann Vasc Surg 1997;11:416-9.

6 Ho CL, Lam JJH, MCAdory LE. Carotid mycotic aneurysm associated with persistent primitive hypoglossal artery. Case report and literature review. J Radio/ Case Rep 2019;13:1-7.

Copyright 2020 BMJ Publishing Group. All rights reserved. For permission to reuse any of this content visit

https://www.bmj.com/company/products-services/rights-and-licensing/permissions/

BMJ Case Report Fellows may re-use this article for personal use and teaching without any further permission.

Become a Fellow of BMJ Case Reports today and you can:

- Submit as many cases as you like

- Enjoy fast sympathetic peer review and rapid publication of accepted articles

- Access all the published articles

- Re-use any of the published material for personal use and teaching without further permission

\section{Customer Service}

If you have any further queries about your subscription, please contact our customer services team on +44 (0) 2071111105 or via email at support@bmj.com.

Visit casereports.bmj.com for more articles like this and to become a Fellow 